\title{
TÜRKIYE' DE BÖLGE PLANLARININ SÜRDÜRÜLEBİLİR KALKINMA HEDEFLERİ İLE UYUMUNUN KARŞILAŞTIRILMASI: GAP, DAP, DOKAP VE KOP ÖRNEKLERİ
}

\section{Bülent DARICI ${ }^{1}$ \\ ÖZ \\ Mehmet Ali CANBOLAT ${ }^{2}$}

Türkiye ekonomisinde planlama süreci ilk olarak Sanayi Planları ile başlamış ve İkinci Dünya Savaşından sonraki dönemlerde ise Kalkınma Planları ile devam etmiştir. Bölgesel gelişmelerin ülke ekonomisi açısından taşıdığı önem, hazırlanan planların şekillendirilmesinde etkili olmuştur. Bu bağlamda geri kalmış yörelerin sosyo-ekonomik bakımdan gelişmiş bölgelerle benzer bir konuma getirilebilmesi için çok sayıda proje hazırlanmıştır. Bu araştırma, Konya Ovası Projesi (KOP), Güneydoğu Anadolu Projesi (GAP), Doğu Anadolu Projesi (DAP) ve Doğu Karadeniz Projesi'nin (DOKAP) enerji ve çevre konularını içeren kısımları ile Birleșmiş Milletler (BM) Sürdürülebilir Kalkınma Hedefleri (SKH) arasındaki uyumun değerlendirilmesini konu edinmektedir.

Anahtar Kelimeler: Bölgesel Projeler, Eylem Planları, Birleşmiş Milletler Kalkınma Hedefleri, UNEP

\section{A COMPARISON OF COMPLIANCE OF REGIONAL PLANS IN TURKEY WITH SUSTAINABLE DEVELOPMENT GOALS: CASES OF GAP, DAP, DOKAP VE KOP ABSTRACT}

Turkey's economy in the planning process started with the first Industrial Plan and the Second World War continued in subsequent periods with the Development Plans. The importance of regional developments in terms of the country's economy has been influential in shaping the prepared plans. In this context, a number of projects have been prepared in order to bring the backward regions to a similar position from the socio-economically developed regions. Our work has been carried out between the parts of the Konya Plateau Project (KPP), the Southeastern Anatolia Project (SAP), the Eastern Anatolia Project (EAP) and the Eastern Black Sea Project (EBSP) including the energy and environment issues and the United Nations Sustainable Development Goals evaluation of harmony.

\footnotetext{
${ }^{1}$ Karamanoğlu Mehmetbey Üniversitesi İ̉BF, Doç.Dr., bulentdarici@gmail.com , ORCID: 0000-0001-9110-0020

2 Karamanoğlu Mehmetbey Üniversitesi SBMYO, Öğr.Gör., malican70@gmail.com ORCID: 0000-0003-1235-9013
} 
Keywords: Regional Project, Action Plans, United Nations Sustainable Development Goals, UNEP

\section{Giriş}

Türkiye Cumhuriyeti, kurulduğu ilk ylllarda bölgesel açıdan belirgin farklılıkları barındırmakta iken; ilerleyen dönemlerde söz konusu gelişmişlik farklarının giderilmesi için önemli çalışmaların yapıldığı bir ülke konumuna gelmiştir. Başkent olarak Ankara'nın belirlenmesi ve kamu iktisadi kuruluşlarının ülke geneline yayılması yönünde yürütülen faaliyetler, bu çalışmalara örnek olarak gösterilebilir. Ancak devlet, her ne kadar yatırımların dengeli dağılımı için çeşitli faaliyetlerde bulunsa da; hedeflenen sonuçlara tam anlamıla ulaşılamamıştır (DPT, 2000: s. 24).

1960 yılından itibaren hükümet programlarında bölgesel sorunlara ve dengesizliklere yönelik olarak şu temel önerilere değinildiği görülmektedir (DPT, 1977: s. 43-44);

- Bölgeler arasındaki ekonomik ve sosyal farkların giderilmesi,

- Aşırı ve sağlıksız kentleşmenin yarattı̆̆ı sorunların ortadan kaldırılması,

- Konut sorununa çözüm getirilmesi,

- Çevre sorunlarını giderici önlemlerin alınması,

- Yerel idarelerin mali açıdan güçlendirilmesi.

Bölgesel sorunları çözüme kavuşturmak üzere farklı hükümet programlarında, aşağıda belirtilen daha özel tedbirlere de yer verildiği dikkat çekmektedir (DPT, 1977: s. 43-44):

- Organize sanayi bölgeleri kurarak, sanayi sektörünün ülke geneline dengeli dağılımını gerçekleştirmek,

- Özel sektörü güçlendirmek, kalkınmaya öncülük edecek şirketler kurmak,

- Köylerde küçük sanayi tesisleri kurmak,

- Toprak ve tarım reformunu gerçekleştirmek,

- Doğu ve Güneydoğu Anadolu Bölgelerinin kalkınmasına hizmet edecek özel projeler uygulamak.

Bölge planlamasının ana teması; bölgeler arasındaki dengesizliklerin giderilmesidir. Fakat bölge planlama deneyimleri, "dengeli dağılım" hedefinin gerçekleștirebilme şansının sadece tesislerin yer seçimini etkilemeye yönelik bölgesel politikalara bağlı olamayacağını göstermiştir. Ülkelerin ekonomik büyümeyi veya bu büyümenin mekânsal dağıtımını hedefleyebilmelerinin parametrelerini kuramsallaştırma arayışları, 1980'li yılların bölgesel gelişme politikalarını etkilemiştir. 1990'lı yıllarda ise küreselleşme

154 | Manisa Celal Bayar Üniversitesi Sosyal Bilimler Dergisi - Cilt: 17, Sayı: 2, Haziran 2019 
ile birlikte bölgesel birliklerin oluşumu, bölge kavramında değişimleri beraberinde getirmiş; küresel/yerel diyalektiği içinde bölgenin değişen anlamı tartışılmaya başlanmıştır. Ayrıca çevre sorunları, "sürdürebilirlik kavramı" çerçevesinde bölgesel stratejilerin belirlenmesin-de bir başka önemli boyut olarak yerini almıştır (DPT, 2000: s. 22).

Dokuzuncu Kalkınma Planında bölgesel gelişme politikaları ile bir taraftan bölgelerin verimliliğini yükselterek ulusal kalkınmaya, rekabet gücüne ve istihdama daha fazla katkı sağlanması amaçlanırken; diğer taraftan da bölgeler arası gelişmişlik farklılıklarının azaltılması hedeflenmiştir. $\mathrm{Bu}$ kapsamda merkezi düzeydeki politikaların daha etkin hale getirilmesi, yerel dinamiklere ve içsel potansiyele dayalı gelişme ortamının desteklenmesi, yerel düzeyde kurumsal kapasitenin artırılması ve kırsal kalkınmanın hızlandırılması için yapılması gereken çalışmaların önemi vurgulanmıştır. Böylece bölgesel gelişme planlarının; esnek, dinamik, katılımcı ve uygulanabilir nitelikte hazırlanması, kalkınma ajanslarıyla işbirliği içinde gelişme stratejilerinin belirlenmesi ve projelerin finanse edilerek desteklenmesi gerektiği ifade edilmiştir (DPT, 2006: s. 91). 1990' lardan beri AB' nin bölgesel politikaları ile uyumlu bir politika tutumu göstermeye çalışan Türkiye, 1990' larda yaşanan ekonomik sorunlar (Göymen, 2005) ve kişi başına düşen gelirin azalması (Arslan, 2005) ile bölgeler arasındaki farklılıkları halen kapatabilmiş düzeyde değildir (Berber ve Çelepçi, 2005). Nitekim bölgelerarası dengesizlikler dünyadaki bütün ülkelerin çözüme kavuşturamadığı bir sorundur (Sevinç, 2011). Bu sorunun çözümünde 1950-70 döneminde uygulanan kamu katkısı ile altyapı ve üretim desteği ya da birikimi olan bölgelerin dünya çapında rekabet gücü kazanmasına yönelik kamu-özel işbirlikleri gerçekleştiriyor olması yaygın öneriler arasındadır (Eraydın, 2004: s. 136).

Öte yandan kalkınma planlarındaki ulusal ve bölgesel gelişme hedeflerine ulaşabilmek için günümüze kadar çeşitli projeler geliştirilerek, bunların tamamlanabilmesi yönünde önemli çalışmalar yürütülmüştür. GAP (Güneydoğu Anadolu Projesi), ZBK (Zonguldak Bartın Karabük Bölgesel Gelişme Projesi), YHGP (Yeşilırmak Havzası Gelişim Projesi), DAP (Doğu Anadolu Projesi) ve DOKAP (Doğu Karadeniz Projesi) söz konusu projelerden bazılarıdır (Tiftikçigil, 2010: s.112).

GAP projesinin başlangıcı 1970'li yılların sonlarına dayanmaktadır. Dönemin siyasi ve teknik kadroları, Fırat ve Dicle nehirleri ile Harran ovası gibi toprakların değerlendirilmesine 
yönelik somut adımlar atarak projenin hayata geçmesine yardımcı olmuşlardır (Karakılçık, 2014: s. 356). GAP; Adıyaman, Batman, Diyarbakır, Gaziantep, Mardin, Siirt, Şanlıurfa, Şırnak ve Kilis illerini içine alan tüm Güneydoğu Anadolu Bölgesi'nin sosyo-ekonomik kalkınmasını amaçlayan bir bölgesel gelişim projesidir. Türkiye' nin bölgesel kalkınmaya yönelik en kapsamlı projesi olan GAP; Fırat ve Dicle nehirleri üzerinde yapımı süren baraj ve hidroelektrik santralleri ile sulama tesislerinin yanı sıra kentsel ve kırsal altyapı, tarım, ulaştırma, sanayi, eğitim, sağlık, konut, turizm ve diğer sektörlerdeki yatırımları da kapsayan bütünleşik ve sürdürülebilir bir yaklaşım içinde devam ettirilmektedir (DPT, 2000: s. 38).

Bir diğer bölgesel kalkınma projesi olan DAP, Doğu Anadolu Bölgesinin gelişim sürecini hızlandırmak üzere; hayvancılık, konut, altyapı, istihdam ve göç gibi konularda kapsamlı bir dizi faaliyetleri içermektedir (Gündüz, 2006: s. 202). Proje kapsamındaki temel amaç ve hedefler şu şekilde sıralanabilir (DPT, 2000: s. 35):

- Bölgenin diğer bölgelere göre geride olan sosyo-ekonomik gelişmesini hızlandıracak politika ve uygulamaları ortaya koymak,

- Sektörel gelişmeleri hızlandırmak üzere çeşitli alanlarda analizler yapmak ve öncelikleri belirlemek,

- Kırsal ve kentsel gelişmeyi sağlayacak önemli kamu yatırımlarını tespit etmek ve özel kesim yatırımlarını özendirici politika ve uygulamaları hayata geçirmek,

- Bölgesel gelişmeyi kamu, yerel yönetimler, özel kuruluşlar ve sivil toplum örgütleri ile işbirliği içinde sağlamak,

- Bölgedeki girişimciliği teşvik etmeye, bölgesel iç dinamikleri harekete geçirmeye ve/veya bölge dışındaki girişimcileri (yabancı sermaye dahil) çekmeye yönelik olarak yatırım alanlarını belirlemek, yatırım projeleri hazırlamak,

- Nitelikli işgücü, teknoloji, finansman vb. konularda somut öneriler geliștirmek, bunların eşgüdümünü sağlayacak kurumsal düzenlemeler önermek ve bu çalışmaları "katılımcılık ilkesi" çerçevesinde gerçekleştirmek,

- Seçilmiş yatırım alanlarında, mevcut potansiyeli değerlendirmek ve yatırımlara yön göstermek amacıyla değişik konularda fizibiliteler hazırlamak,

- Bölgesel istihdamın geliştirilmesi açısından önem taşıyan işgücü arz ve talebinin sektörel ve mekânsal analizini yapmak,

- Bölgedeki insan kaynaklarının geliştirilmesi konusunda sektörel yeni projeler önermek. 
Türkiye'nin kuzey-doğusundaki 7 ili kapsayan ve bölgenin potansiyelini harekete geçirerek gelişmişlik farklarını azaltmayı hedefleyen DOKAP ana planı, 10 programdan meydana gelmektedir. $\mathrm{Bu}$ programların üçü, alt-yapı faaliyetlerini iyileștirmeye ve toprak verimliliğini artırmaya; üçü, ekonomik yapıyı güçlendirmeye; üçü, idari, sosyal ve çevresel sorumluluğu güçlendirmeye ve biri de DOKAP kimliğinin oluşturulmasına yöneliktir (Dinler, 2014: s. 223225).

Bölgesel kalkınma projelerinden biri olan KOP ise 1985 yılında başlamış olup, Konya ve ilçelerine iliş̧in Devlet Su İşleri (DSi) yatırımlarını içerecek şekilde tasarlanmıştır. Daha sonra projenin kapsamı; Karaman, Niğde ve Aksaray illeri de dâhil edilerek genişletilmiştir. Dolayısıyla KOP Bölgesi; DSİ, İl Özel İdareleri ve Halk Sulamaları tarafından yapılan bütün sulama projeleri ile hidroelektrik enerji santrallerini ve içme suyu projelerini de içerecek hale getirilmiştir (www.kop.gov.tr. ET: 14.11.2017).

Bölgesel planlama anlayışı ve GAP deneyimi çerçevesinde, 2011 yılında 642 Sayllı Kanun Hükmünde Kararname ile Doğu Anadolu Projesi (DAP BKI), Doğu Karadeniz Projesi (DOKAP BKI) ve Konya Ovası Projesi (KOP BKİ) Bölge Kalkınma İdareleri kurulmuştur. İdareler, bölgelerin kalkınması yönünde kamu yatırımlarının koordinasyonunu sağlamak, ağırlığı kamu yatırım, proje ve faaliyetlerinde olmak üzere kalkınma ajanslarıyla işbirliği içinde eylem planlarını hazırlamakla görevlendirilmiştir. Bu eylem planlarının temelini oluşturan ana unsurlardan birisi de bölge planlarıdır. Kalkınma ajanslarının koordinasyonunda hazırlanan bölge planları eylem planlarının sorun, durum tespitinde ve amaçların/stratejilerin belirlenmesinde olduğu gibi geliştirilen eylemlerde de temel teşkil etmiştir (Kalkınma Bakanlığı "GAP Eylem Planı", 2014: s. 11).

Bölgesel çalışmaların amacı çerçevesinde daha iyi bir yaşam için BM Sürdürülebilir Kalkınma Hedefleri, ilk olarak milenyumda sekiz hedef olarak belirlenmiştir. Bu hedeflerin süresi 2015 yılında sona ermiş ve yine aynı yıl 2030 hedefleri ortaya konulmuştur. BM Sürdürülebilir Kalkınma Hedefleri ismini taşıyan toplam 17 hedef bulunmaktadır. Bu hedeflerin ise önemli bir bölümü enerji ve çevre konusu ile doğrudan veya dolaylı etkileşim halindedir.

Buradan hareketle çalışma; GAP, DAP, DOKAP ve KOP Eylem Planları (2014-2018) içerisinde yer alan enerji ve çevre konusu ile ilgili alanların, BM tarafından ortaya konulan Sürdürülebilir Kalkınma Hedefleri' ne hangi ölçüde uyumlu olduğunu ortaya 
koyarak, elde edilen bulgulardan hareketle yapılacak yeni eylem planları için öneriler getirilmesine dayanmaktadır.

\section{Eylem Planları 2014-2018}

2014-2016 ve 2015-2017 Dönemi Orta Vadeli Program'da "GAP, DAP, KOP ve DOKAP bölgelerinde eylem planları kapsamında; özel sektör yatırımlarını destekleyecek ekonomik ve sosyal altyapı ile beşeri kaynakların geliştirilmesine yönelik projelerin ve eylem planlarındaki diğer projelerin gerçekleștirilmesine devam edilecektir" ve "bölgesel gelişme politikalarıyla bölgeler arası gelişmişlik farkları azaltılacak, tüm bölgelerin potansiyeli değerlendirilerek bölgesel rekabet güçleri artırılacak ve büyümeye katkıları azami seviyeye çıkarılacaktır" ifadeleri üzerine 2014-2018 yıllarını kapsayan eylem planları yapılmıştır (Kalkınma Bakanlığı "KOP Eylem Planı", 2014: s. 13).

Bu bölümde; GAP, DAP, DOKAP ve KOP Eylem Planlarındaki (2014-2018) çevre ve enerji konularına ilişkin bakış açıları ele alınacaktır.

\subsection{GAP Eylem Planında Çevre ve Enerji Konusu}

GAP, Güneydoğu Anadolu Bölgesi'nin kalkınmasına yönelik; Adıyaman, Gaziantep, Kilis, Diyarbakır, Şanlıurfa, Batman, Mardin, Siirt ve Şırnak olmak üzere 9 ili kapsayacak şekilde uygulanan ve koordinasyonu GAP İdaresi Başkanlığı'nca yürütülen Türkiye'deki ilk bölgesel kalkınma projesidir (Efe ve Akgül, 2011: s.189).

GAP Eylem Planı, çevre konusunda şu ifadelere yer vermektedir: "GAP EP (Eylem Planı)(2014-2018); birinci Eylem Planı kapsamında devam eden yatırımları tamamlamak, yapılan yatırımlarla doğan potansiyeli ekonomik, sosyal ve kültürel gelişimin hızlandırılması yönünde tam olarak kullanmak, Bölge'nin rekabet gücünü artırmak ve GAP'ı daha ileriye taşımak amacıyla hazırlanmıştır. Eylem Planı'nda insanı hedef alan, yenilikçi, sürdürülebilir, gelir eşitsizliğini giderici, dezavantajlı alanları ve grupları önceleyen ve yaşanabilir mekânlar oluşturan proje ve programlara yer verilmiştir. Bölgesel gelişmeye ivme kazandıracak, eğitimli ve nitelikli insan gücüne dayall, istihdamı artıran, doğal kaynakları, kültürel mirası ve çevreyi koruyan, teknolojik gelişmeleri ön plana alan, sulama, ulaşım ve sanayi altyapısının tamamlanmasını amaçlayan proje ve programlar planın temel eylemleri arasındadır."(Kalkınma Bakanlığı "GAP Eylem Planı", 2014: s. 15). 
Gelişme ekseni ve eylemler kısmında ise; şehirlerde yaşam kalitesi, kentsel altyapı, konut-kentsel dönüşüm başlıklarında çevre kavramını önceleyen bir yaklaşım kendisini göstermektedir.

Enerji konusu ile ilgili olarak GAP Eylem Planı'nda yer alan ifadeler de şu şekildedir: "GAP enerji yatırımlarında sona gelinmiş; sulama yatırımlarında, işsizliğin ve göç sorunlarının giderilmesinde, ihracatın artırılmasında, Bölge' nin ekonomik ve sosyal göstergelerinin iyileştirilmesinde önemli mesafeler kat edilmiştir. GAP enerji projelerinde \%74 fiziki gerçekleşme sağlanmıştır. Fiziki gerçekleşmesi yaklaşık \%70' lere ulaşan Ilısu Barajı ve HES' in tamamlanmasıyla bu oran \%90' I aşacak, Cizre Projesi'nin gerçekleștirilmesiyle \%93'e ulaşacaktır. Issletmede olan 10 hidroelektrik santralinin toplam kurulu gücü 5.530 MW, yıllık elektrik üretim potansiyeli ise 20,6 milyar kilovat-saattir. GAP kapsamındaki HES' lerin işletmeye alınışından 2013 yılı sonuna kadar ürettiği toplam enerji miktarı 392,1 milyar kilovat-saattir. Bu üretimin parasal değeri ise 23,5 milyar dolardır. Türkiye'de her yıl üretilen hidrolik enerjinin yarısı Bölge'deki hidroelektrik santrallerinden karşılanmakta ve GAP enerji projeleriyle ülke ekonomisine doğrudan katkı sağlamaktadır (Kalkınma Bakanlığı "GAP Eylem Planı", 2014: s. 18)". Ayrıca "GAP Bölgesi için hazırlanan Rekabet Gündemi Calışması çerçevesinde organik tarımın geliştirilmesi, yenilenebilir enerji ve enerji verimliliğinin artırılması, Bölge'nin turizm potansiyelinin ekonomik kalkınmaya katkı sağlayacak şekilde değerlendirilmesine yönelik proje ve faaliyetlere önem verilmiş; pilot uygulamalara başlanmıştır. Bu uygulamaların geliştirilerek sürdürülmesi rekabet gücünün artırılması açısından önem taşımaktadır." (Kalkınma Bakanlığı "GAP Eylem Planı", 2014: s. 25) ifadeleri ile yenilebilir enerji alanında yapılan çalışmalara da vurgu yapılmiştır.

Tablo 1'de 2014-2018 yıllarını kapsayan GAP Eylem Planının gelişme eksenleri ve buna ait alt hedefler yer almaktadır.

2008-2012 yıllarını kapsayan GAP Eylem Planında; Ekonomik Kalkınmanın Gerçekleştirilmesi, Sosyal Gelişmenin Sağlanması, Altyapının Geliştirilmesi ve Kurumsal Kapasitenin Geliştirilmesi olmak üzere 4 gelişme ekseni bulunmaktadır. Bu eksenler altında 73 ana eylem yer almaktadır (Akpınar vd. 2011, s: 164). Bunun yanı sıra II. GAP Eylem Planı beş gelişme ekseni etrafında şekillendirilmiştir. $\mathrm{Bu}$ eksenler is şu şekilde sıralanabilir: Ekonomik Kalkınmanın Hızlandırılması, Sosyal Gelişmenin Güçlendirilmesi, Şehirlerde Yaşanabilirliğin Artırılması, Altyapının Geliştirilmesi ve Kurumsal Kapasitenin Geliştirilmesi. Eylem Planına bakıldığında; 5 gelişme ekseni, 29 alt eksen ve 115 eylem bulunmaktadır. Alt eksenler içinde 
en çok hedef; tarım, sağlık, eğitim, sanayi ve sosyal hizmet ve yardımlar başlıkları altındadır. Doğal kaynaklar ve yenilenebilir enerji alt ekseninde 4, enerji alt ekseninde ise 3 hedef bulunmaktadır.

Tablo 1. GAP Eylem Planı Gelişme Ekseni ve Eylemleri

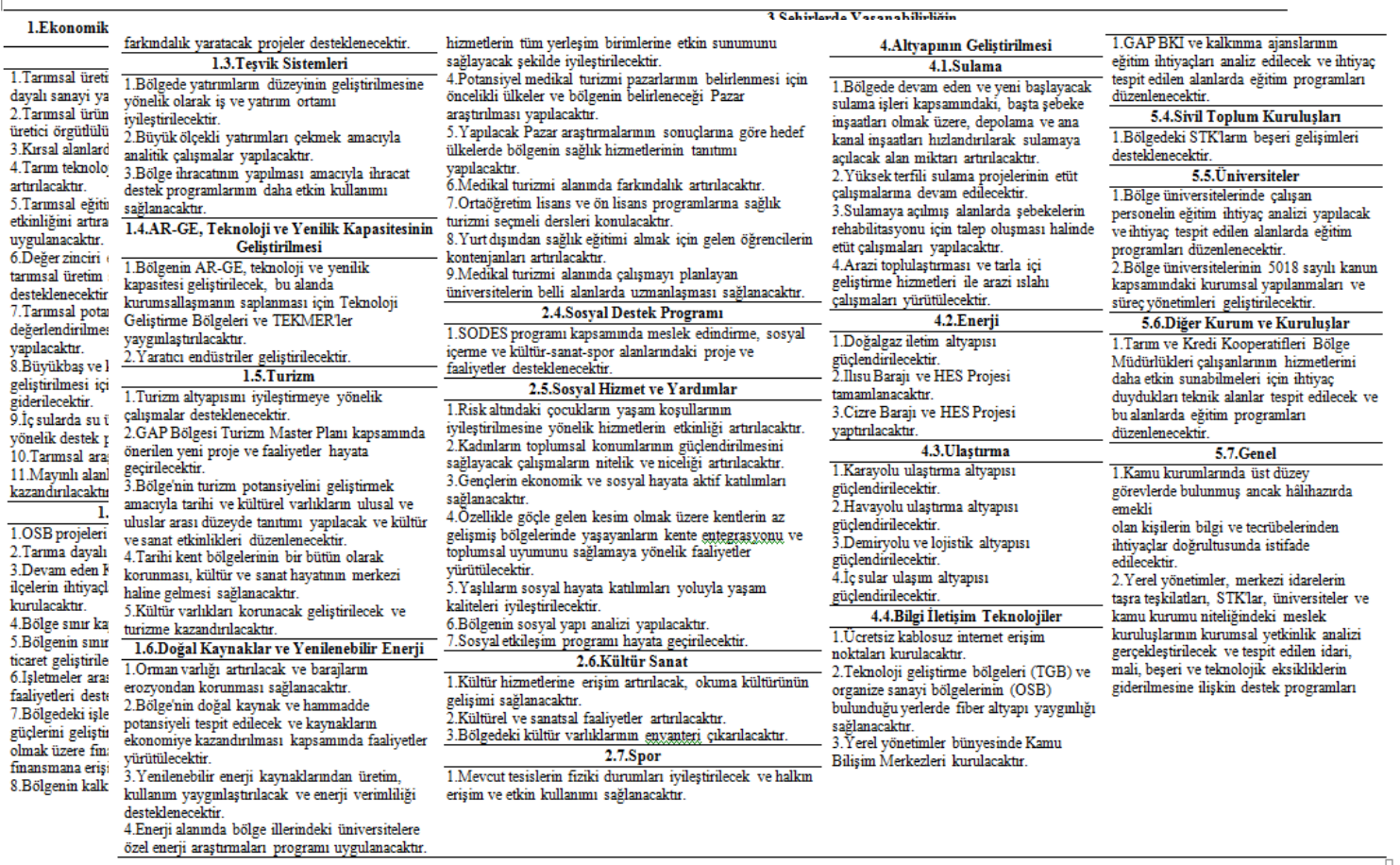

\subsection{DAP Eylem Planında Çevre ve Enerji Konusu}

DAP, ekonomik ve sosyal açıdan Türkiye'nin geri kalmış bölgelerinden biri olan Doğu Anadolu Bölgesi'nin kalkınması için geliştirilmiş ve 2000-2020 yılları arasında sürdürülmesi planlanan bir bölgesel kalkınma projesidir. Proje; Ağrı, Ardahan, Bingöl Bitlis, Bayburt, Elazı̆̆, Erzurum, Gümüşhane, Hakkari, Iğdır, Kars, Malatya, Muş, Tunceli ve Van olmak üzere bölgedeki 16 ili kapsamaktadır (Efe ve Akgül, 2011: s.179).

DAP Eylem Planı ile temel olarak; Doğu Anadolu Bölgesi'nde yaşayan nüfusun; ekonomik, sosyal ve çevresel yaşam kalitesini artırmak ve bölgenin refah düzeyini ülke ortalaması ile eşdeğer hale getirmek amaçlanmaktadır. Planda ayrıca çevre ve insan sağlığının korunmasına yönelik olarak entegre katı atık yönetim projelerinin de bulunduğu görülmektedir. Yine altyapı, kentleşme ve çevre koruma ekseni başlığında: 27 farklı eylemin bulunduğu ve bu eylemlerin pek

160 | Manisa Celal Bayar Üniversitesi Sosyal Bilimler Dergisi - Cilt: 17, Sayı: 2, Haziran 2019 
çok farklı kuruluşla işbirliği içinde yürütüleceği ifade edilmektedir (Kalkınma Bakanlığı "DAP Eylem Planı", 2014).

Enerji konusunda ise özellikle yenilenebilir enerji üretimine imkan veren baraj yapım faaliyetlerinin devamı yönünde bilgiler bulunmaktadır. Diğer yenilenebilir enerji kaynaklarından (güneş, biyogaz, rüzgar vs.) elde edilen enerji miktarını artırmak üzere yürütülmekte olan çalışmaların da sürdürüleceği belirtilmektedir (Kalkınma Bakanlığı "DAP Eylem Planı", 2014).

Tablo 2' de 2014-2018 yıllarını kapsayan DAP Eylem Planının gelişme eksenleri ve buna ait alt hedefler yer almaktadır.

DAP Eylem Planı beş gelişme ekseni etrafında şekillenmektedir. Bunlar; Gıda ve Tarım Sektörlerinde Verimlilik ve Katma Değerin Artırılması, Sanayi ve Hizmetler Sektörlerinin Güçlendirilmesi, Altyapı, Kentleşme ve Çevre Koruma, Beşeri-Sosyal Sermayenin ve Sosyal Altyapının Güçlendirilmesi, Kurumsal Kapasitenin Geliştirilmesi şeklinde sıralanabilir. Plan genel itibariyle; 5 gelişme ekseni, 27 alt eylem ve 126 eylemden meydana gelmektedir. Alt eksenler içinde en çok hedef; eğitim, sağlık, kültürgençlik hizmetleri ve spor başlıkları altında yer alırken; çevre alt ekseninde 5, enerji alt ekseninde ise 3 hedef bulunmaktadır. 


\section{Tablo 2. DAP Eylem Planı Gelișme Ekseni ve Eylemleri}

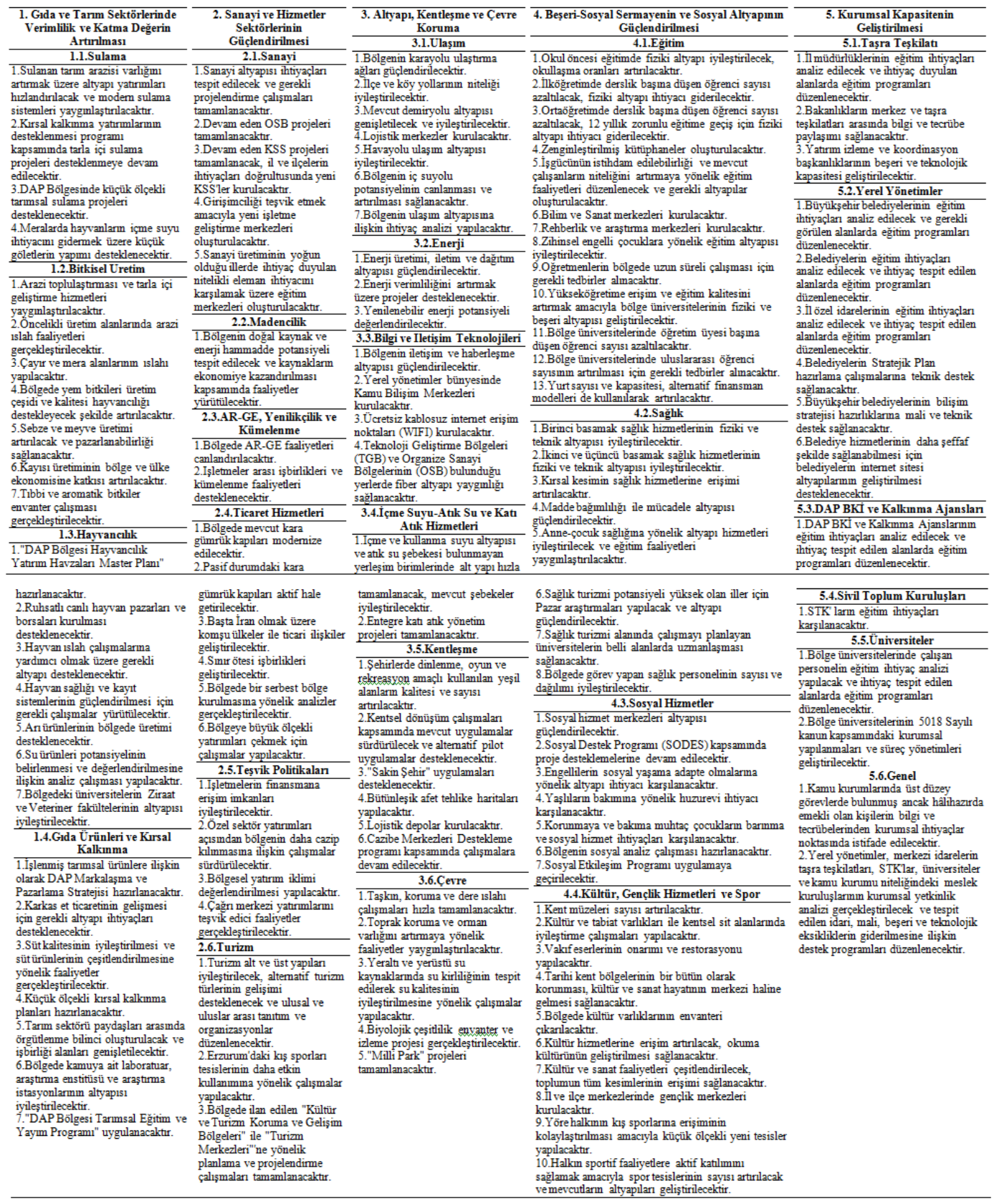




\subsection{DOKAP Eylem Planında Cevre ve Enerji Konusu}

DOKAP, DPT' nin teknik desteği ve koordinasyonunda Japonya Uluslararası İşbirliği Ajansı (JICA) ile birlikte, Doğu Karadeniz Bölgesinde yer alan 7 ilin (Artvin, Giresun, Gümüşhane, Ordu, Rize, Trabzon ve Bayburt) ekonomik, sosyal ve kültürel açıdan geliştirilmesi için hazırlanmıştır (Efe ve Akgül, 2011: s.183).

Çevre konusu ile ilgili olarak planda şu ifadelere yer verilmektedir: "DOKAP Bölgesi sahip olduğu zengin doğal kaynaklar neticesinde etkili bir çevre yönetimi sistemine ihtiyaç duymaktadır. Özellikle günümüz dünyasında çevre kirliliğinin artış göstermesi ve buna bağlı olarak doğal kaynakların kontrolsüz olarak tüketilmesi çevre kaynaklarının korunmasını stratejik bir alana taşımıştır. DOKAP Bölgesi gibi doğa turizminde önemli bir cazibe merkezi olan bir bölgenin koruma-kullanma dengesi dâhilinde, etkin bir çevre yönetimine sahip olması büyük önem arz etmektedir. Bölgede çevresel kirleticilerin başında evsel atıklar gelmektedir. Bunun yanında findık ve çay tarımının yapıldığı alanlarda yanlış tarım teknikleri sonucunda yer altı suyu kaynakları ve akarsu kaynaklarının belirli oranda kirlendiği gözlenmektedir. Bölge kirleticilerinden birisi olan katı atıkların bütüncül bir yaklaşım ile çözülmesi yerinde olacaktır. II merkezleri için düzenli katı atık depolama sahaları ile ilgili çalışmalar yürütülürken kırsal alanlar için düzenli toplama ve depolama sorunları devam etmektedir. Bu kapsamda yürütülen münferit çözümlerin yeterli olmadığı gözlenmektedir. Bu kapsamda; bölge genelinde doğal hayatın korunması sağlanarak biyolojik çeşitliliğin tespitinin yapılması, Milli Park Projelerinin tamamlanması, biyo-kaçakçılıkla ilgili etkin mücadelenin sürdürülmesi, bölge genelinde tarımsal kirliliğin izlenmesi ve azaltılması ile ilgili çalışmaların gerçekleştirilmesi, kırsal kesiminde oluşan evsel atıkların toplanması ve Entegre Katı Atık Yönetim Projelerinin tamamlanması önemli ihtiyaç alanları olarak göze çarpmaktadır." (Kalkınma Bakanlığı "DOKAP Eylem Planı", 2014: s. 44-45).

Eylem planı çerçevesinde enerji konusu ile ilgili olarak ise şu ifadeler bulunmaktadır; "DOKAP Bölgesi sahip olduğu doğal kaynaklar nedeni ile yenilenebilir enerji konusunda da önemli potansiyele sahiptir. Sahip olunan bu potansiyelin gerekli araştırmaların yapılarak kullanıma kazandırılması, ülke olarak sorun yaşadığımız enerji açığı konusunda önemli katkılar sağlayacaktır. Bununla birlikte bölge genelinde enerji alt yapısının iyileştirilmesi, sanayi ve diğer iş kollarının gelişiminde de başat etki sağlayacaktır. Doğu Karadeniz Bölgesi coğrafi konumu ve sahip olduğu zengin su kaynakları neticesinde birçok Hidroelektrik Santraline de (HES) ev sahipliği yapmaktadır. 
DOKAP Bölgesinde aktif ve yapımı devam eden 271 adet lisanlı HES bulunmaktadır. Söz konusu HES' lerin toplam 6.011 MW elektrik üretim kapasitesi bulunmaktadır. Bölgede yer alan HES yapılarının çevreye duyarlı üretim yapmaları konusunda alınan yasal tedbirlerin uygulanması büyük önem arz etmektedir. Ayrıca madencilik ile ilgili, bölgenin doğal kaynak ve enerji hammadde potansiyellerinin tespit edilerek, çevre konusunda azami hassasiyet gösterilerek kaynakların ekonomiye kazandırılması büyük önem arz etmektedir. Bu kapsamda enerji alt yapısının geliştirilmesi ve yenilenebilir enerji konularında gerekli çalışmaların yapılması önemli ihtiyaç alanları olarak belirlenmiştir. Ayrıca bölge genelinde eksik kalan doğalgaz iletim hatlarının tamamlanarak bölgenin enerji üretim altyapısının iyileştirilmesi, bölgenin enerji dağıtım altyapısının iyileștirilerek bölgede yenilenebilir enerji çalışmalarının desteklenmesi bölge potansiyellerinin ortaya çıkarılmasında önemli katkılar sağlayacaktır." (Kalkınma Bakanlığı "DOKAP Eylem Planı", 2014: s. 40-41).

Tablo 3' de 2014-2018 yıllarını kapsayan DOKAP Eylem Planının gelişme eksenleri ve buna ait alt hedefler yer almaktadır.

DOKAP Eylem Planı beş gelişme ekseni etrafında şekillenmektedir. Bunlar; Turizm ve Çevresel Sürdürülebilirlik, Ekonomik Kalkınma, Altyapı ve Kentsel Gelişme, Sosyal Gelişme, Yerel Düzeyde Kurumsal Kapasitenin Geliştirilmesi biçiminde sıralanmaktadır. Plan genel itibariyle; 5 gelişme ekseni, 20 alt eksen ve 129 eylemden oluşmaktadır. Alt eksenler içinde en çok hedef; tarım, sanayi, girișimcilik, AR-GE, turizm, sosyal hizmetler ve destekler başlıkları altında yer alırken; çevresel sürdürülebilirlik alt ekseninde 6 ve enerji alt ekseninde ise 4 hedef bulunmaktadır.

\subsection{KOP Eylem Planında Çevre ve Enerji Konusu}

Bölge Kalkınma İdaresi tarafından, Aksaray, Karaman, Konya ve Niğde illerinde 2012 yılından bu yana yürütülen saha araştırmaları, sektör analizleri ve farklı düzeylerdeki paydaş görüşmeleri neticesinde hazırlanmış olan KOP Eylem Planı, bölge insanının refah seviyesini ve bölgenin gelişme potansiyelini artıracak, bölge üretimini daha sürdürülebilir ve dengeli hale getirecek tedbirler içermektedir. KOP Eylem Planı'nın temel amacı bölgede kapsamlı bir dönüşümü gerçekleştirmektir. Bu çerçevede tarımsal yapıda değişimi ve sürdürülebilirliği sağlayarak; sanayi, ticaret, ulaşım ve enerji gibi sektörleri güçlendirmek, eğitim, sağlık, kültür ve diğer sosyal hizmetlere erişilebilirliği artırmak ve yenilikçi bir yaklaşımla bölgenin rekabet gücünü geliștirmek, temel öncelikleri oluşturmaktadır.

164 | Manisa Celal Bayar Üniversitesi Sosyal Bilimler Dergisi - Cilt: 17, Sayı: 2, Haziran 2019 
Tablo 3. DOKAP Eylem Planı Gelişme Ekseni ve Eylemleri

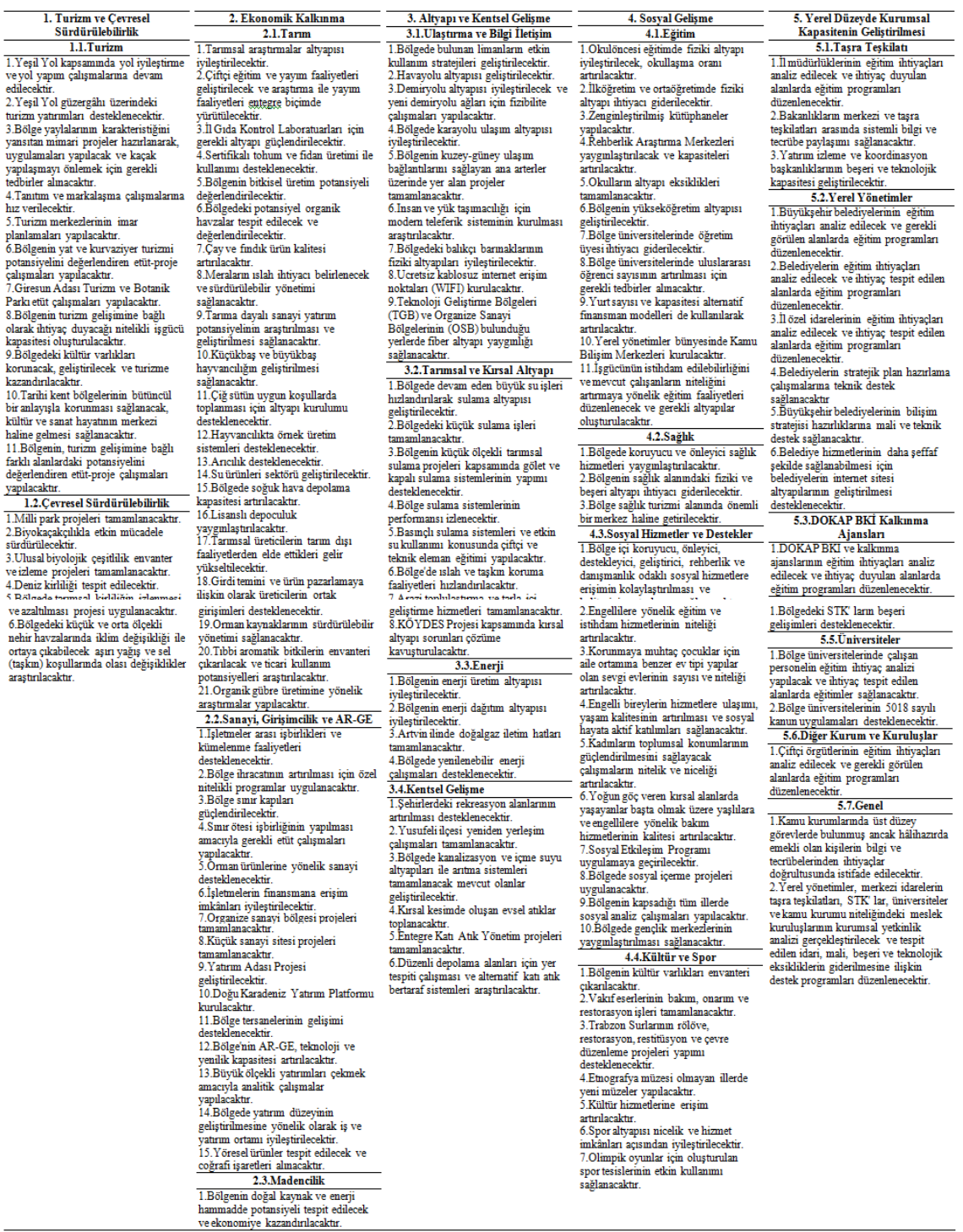

KOP Eylem Planı 30.12.2014 tarihinde Bölgesel Gelişme Yüksek Kurulu tarafindan onaylanmış ve 30.04.2015 tarihinde Niğde'de gerçekleştirilen KOP Eylem Planı Tanıtım Toplantısı ile kamuoyuna açıklanmıştır (www.kop.gov.tr. ET: 14.11.2017).

Planda çevre konusu ile ilgili şu ifadeler yer almaktadır: "Bölgenin sahip olduğu su kaynakları varlı̆̆ı ile toprak kaynakları varlığı arasındaki dengesizlik, son yıllarda kullanılabilir su potansiyeli 
aleyhine bozularak tarımsal ve çevresel sürdürülebilirliği tehdit eder duruma gelmistir. Bu nedenle bölgede, salt tarım odakl kalkınma anlayışından çok sektörlü bir kalkınma anlayışına geçilmesi gerekmektedir. Bölgede çevresel sürdürülebilirliğin sağlanması için sanayide atık azaltımının sağlanması ve kaynak verimliliğine yönelik faaliyetlerin artırılmasının yanı sıra sulu kuru tarım alanlarında dikey toprak işlemenin ve ÇATAK kapsaminda doğrudan ekim yeşil gübre uygulamalarının yaygınlaştırılmasi; orman alanlarında toprak muhafazası, erozyon kontrolü, çölleşme ile mücadele için ağaçlandırma çalışmaları yapılacaktır." (Kalkınma Bakanlığı "KOP Eylem Planı", 2014: s. 49-51).

Altyapı ve kentleşme ile ulaştırma ve enerji alt başlı̆̆ında ise şu ifadeler bulunmaktadır: "Bu çerçevede, hem bölgenin dönüşümü hem de alt merkez olarak diğer bölgelerle etkileşimine ve sektörel dönüşümüne katkı yapacak ulaşım ağının kurulması, enerji sektörlerinde kilit yatırımların programlanması ve bunların hayata geçirilmesi büyük önem kazanmaktadır. Bölgede kurulan/ kurulabilecek enerji tesislerinin koordinasyonu sağlanacak, yerli ve yenilenebilir enerji üretiminin yaygınlaştırılmasına ilişskin araştırmalar yapılacak, enerji verimliliği eğitimleri ve bilinçlendirme faaliyetleri düzenlenecektir." (Kalkınma Bakanlığı "KOP Eylem Planı", 2014: s. 3653).

Tablo 4'de 2014-2018 yıllarını kapsayan KOP Eylem Planının gelişme eksenleri ve buna ait alt hedefler yer almaktadır.

KOP Eylem Planı beş gelişme ekseni etrafında şekillenmektedir. Bunlar; Toprak ve Su Kaynaklarının Sürdürülebilir Kullanımı, Ekonomik Yapının Güçlendirilmesi, Altyapının Geliştirilmesi ve Kentleşme, Beşeri ve Sosyal Yapının Güçlendirilmesi ve Kurumsal Kapasitenin Geliştirilmesi şeklinde sıralanabilir. Eylem Planı genel itibariyle; 5 gelişme ekseni, 26 alt eksen ve 92 eylemden meydana gelmektedir. Alt eksenler içinde en çok hedef; Su Kaynaklarının Sürdürülebilir Kullanımı ve Havza Su Yönetimi, Eğitim, Sanayi, Girişimcilik ve Kümelenme, Yerel Yönetimler başlıkları altında yer alırken; Çevre Koruma alt ekseninde 4, Enerji Altyapısı alt ekseninde 1 ve Yenilenebilir Enerji alt ekseninde ise 1 hedef bulunmaktadır. 
Türkiye' de Bölgesel Çalışmalar: GAP, DAP, DOKAP ve KOP Planlarının Çevre ve Enerji Bağlamında Değerlendirilmesi, Sürdürülebilir Kalkınma Hedefleri ile Uyumunun Karşılaştırılması

Tablo 4. KOP Eylem Planı Gelişme Ekseni ve Eylemleri

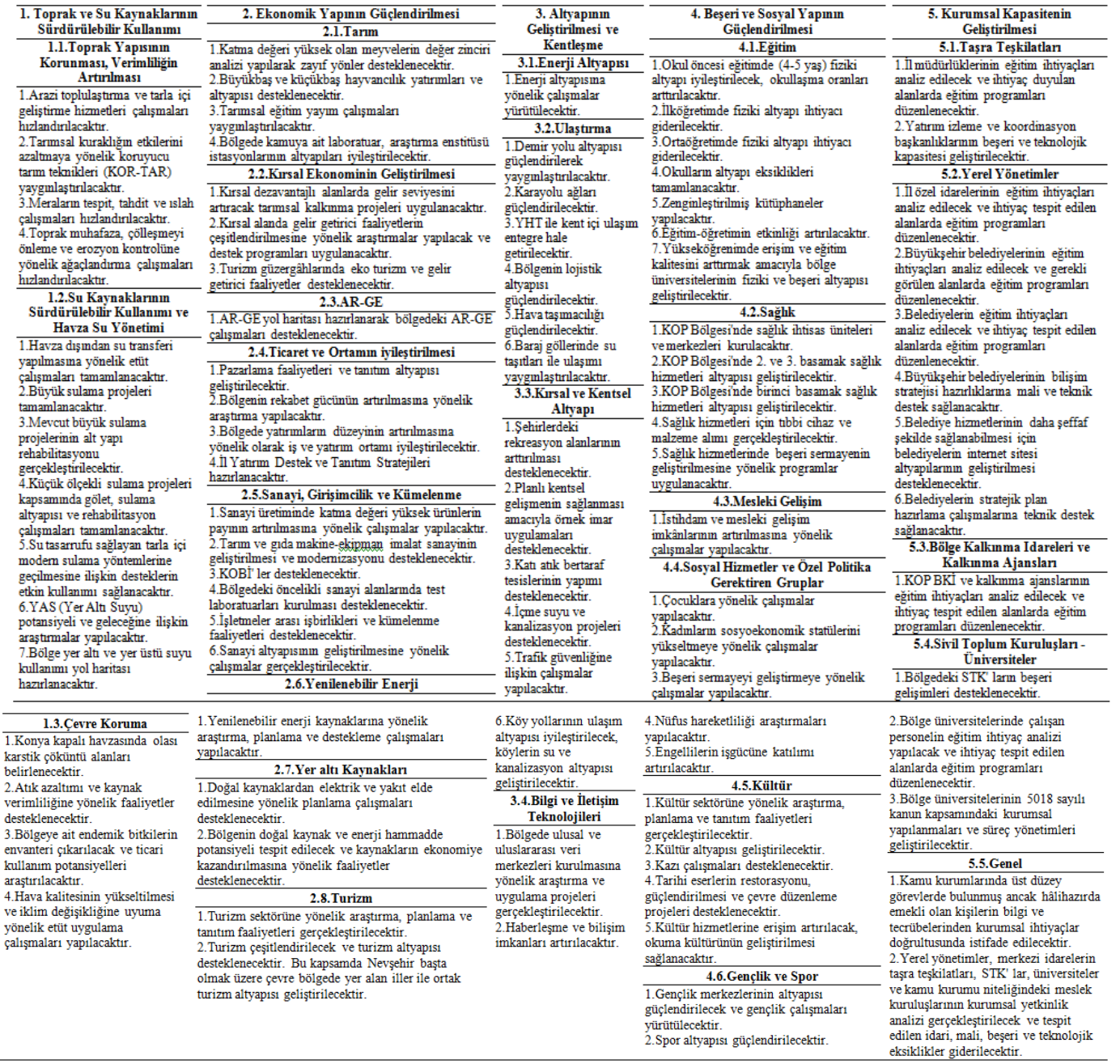

\section{Birleşmiş Milletler Sürdürülebilir Kalkınma Hedefleri ve BM Çevre Programı (UNEP) Çalışmaları}

Yoksulluk, sağlık, eğitim, cinsiyet eşitliği, çevre ve insan refahını etkileyen birçok konuda 60 göstergeyi kapsayan Binyıl Kalkınma Hedefleri (BKH), gerek küresel düzeyde gerekse ülkeler bazında en geniş tanımlı kalkınma ve yoksullukla mücadele değişkenlerini ortaya koymaktadır. Kalkınma olgusuna gelir gibi sadece parasal göstergelerle değil; aynı zamanda gelir dışındaki birçok parasal olmayan göstergeyle de bakmamızı sağlayan BKH, 
ülkelere çok boyutlu hedefler belirleyerek gerekli politikaların oluşturulmasına katkı sunmaktadır. BM'nin, Uluslararası Para Fonu (IMF), Dünya Bankası (WB), Ekonomik Kalkınma ve İşbirliği Teşkilatı (OECD) ve Avrupa Birliği (AB) gibi uluslararası kuruluşlar ile işbirliği yaparak belirlemiş olduğu BKH bir bakıma, 1990'lı yıllarda uluslararası konferanslar ve zirvelerde dile getirilmiş olan kalkınma hedeflerinin bir ifadesidir. Bu hedefler, Eylül 2000'de "Binyıl Deklarasyonu" ile açıklanmış olup, daha sonraki dönemde eklemeler ile 8 genel amaç çerçevesinde 21 hedef ve 60 göstergeyi kapsayan, gelişmekte olan ülkeler tarafından 2015 yılına kadar da ulaşılması planlanan ölçülebilir ve izlenebilir hedefler haline gelmiştir (Halisçelik, 2015: s.1).

Binyıl Kalkınma Hedeflerinin bitiminin ardından, bu kez yeni bir 15 yıllık ve adı Sürdürülebilir Kalkınma Hedefleri (SKH) olarak değiştirilen hedefler seti ortaya konulmuştur. "New York' taki Birleşmiş Milletler Genel Merkezinde 25-27 Eylül tarihlerinde gerçekleştirilen BM Sürdürülebilir Kalkınma Zirvesinde 2030 Sürdürülebilir Kalkınma Hedefleri 193 ülkenin imzası ile kabul edilmiştir. Bu yeni gündem insanlar, gezegen ve refah için bir eylem planıdır, aynı zamanda daha geniş özgürlük anlayışı içerisinde dünya barışını güçlendirmeyi amaçlamaktadır. Her boyutuyla yoksulluğun ortadan kaldırlması sürdürülebilir kalkınma için vazgeçilmez bir gerekliliktir. Tüm ülkeler ve paydaşlar işbirliği içinde hareket ederek bu planı uygulamaya koyacaktır. Yayınlanan 17 Sürdürülebilir Kalkınma Hedefleri ve 169 alt başlığı yeni Küresel Gündemin amaç ve boyutlarını göstermektedir. Bunlar aşağıda verilmiştir (http://unesco.org.tr/dokumanlar/duyurular/skh.pdf ET: 30.11.2017):

Hedef 1. Her tür yoksulluğu, nerede olursa olsun sona erdirmek, Hedef 2. Açlı̆ğ bitirmek, gıda güvenliğini sağlamak, beslenme imkânlarını geliştirmek ve sürdürülebilir tarımı desteklemek, Hedef 3. İnsanların sağlıklı bir yaşam sürmelerini ve herkesin her yaşta refahını sağlamak,

Hedef 4. Herkesi kapsayan ve herkese eşit derecede kaliteli eğitim sağlamak ve herkese yaşam boyu eğitim imkânı tanımak, Hedef 5. Toplumsal cinsiyet eșitliğini sağlamak, kadınların ve kız çocuklarının toplumsal konumlarını güçlendirmek,

Hedef 6. Herkes için suya ve sağlıkl yaşamaya erişimi ve suyun ve sağlıklı yaşamanın sürdürülebilir yönetimini garanti altına almak, Hedef 7. Herkes için erişilebilir, güvenilir, sürdürülebilir ve modern enerji sağlamak,

168 | Manisa Celal Bayar Üniversitesi Sosyal Bilimler Dergisi - Cilt: 17, Sayı: 2, Haziran 2019 
Hedef 8. Sürdürülebilir ve kapsayıcı ekonomik kalkınmayı sağlamak, tam ve üretici istihdamı ve insan onuruna yakışır işleri sağlamak,

Hedef 9. Dayanıklı altyapı inşa etmek, sürdürülebilir ve kapsayıcı sanayileșmeyi ve yeni buluşları teşvik etmek, Hedef 10.Ülkelerin içinde ve aralarındaki eşitsizlikleri azaltmak, Hedef 11. Kentleri ve insan yerleşim yerlerini herkesi kucaklayan, güvenli, güçlü ve sürdürülebilir kılmak,

Hedef 12. Sürdürülebilir tüketimi ve üretimi sağlamak,

Hedef 13. Íklim değişikliği ve etkileri ile mücadele için acil olarak adım atmak,

Hedef 14.Okyanusları, denizleri ve deniz kaynaklarını sürdürülebilir kalkınma için korumak ve sürdürülebilir şekilde kullanmak,

Hedef 15. Karasal ekosistemleri korumak, restore etmek ve sürdürülebilir kullanımını sağlamak, ormanların sürdürülebilir kullanımını sağlamak, çölleşme ile mücadele etmek, toprakların verimlilik kaybını durdurmak ve geriye çevirmek ve biyoçeşitlilik kaybını durdurmak,

Hedef 16. Sürdürülebilir kalkınma için barış̧ıll ve herkesi kucaklayan toplumları teşvik etmek, herkesin adalete erişimini sağlamak, her seviyede etkin, hesap verebilir ve kucaklayıcı kurumlar inşa etmek, Hedef 17. Sürdürülebilir kalkınma için küresel ortaklı̆̆ın uygulama araçlarını güçlendirmek ve küresel ortaklığı yeniden canlandırmak"

Birleşmiş Milletlerin bir alt kuruluşu olan Birleşmiş Milletler Çevre Programı (The United Nations Environment Programme, UNEP), çevre konusu ile ilgili çalışmalarını Sürdürülebilir Kalkınma Hedeflerini de içeren bir platformda yürütmektedir. UNEP' in ilgilendiği konular arasında; küresel çevre gündemini belirlemek, sürdürülebilir kalkınmanın çevresel boyutunun Birleşmiş Milletler sistemi içinde tutarlı bir şekilde uygulanmasını teşvik etmek ve küresel çevre için yetkili bir savunucu görevini üstlenmek yer almaktadır (https://www.unenvironment.org/ about-unenvironment ET: 30.11.2017).

Tablo 5'de 17 sürdürülebilir kalkınma hedefi ile UNEP' in çalışma alanına giren konular ilişkilendirilmektedir. Tablonun son sütunu ise erişim tarihi (14.11.2017) itibariyle konu başlıklarına göre ele alınmış çalışma materyallerini ve sayısını göstermektedir. Yine son sütun dikkate alındığında 8822 çalışmanın, 2411' i çevre yönetimi, 1921' i iklim değişikliği, 1355' i ekosistem konuları hakkında yapılan çalışmaları ifade etmek üzere en fazla çalışma yapılan alanları belirtmektedir. Diğer sütunlar içinde bulunan (X) işareti, yapılan çalışmanın hangi SKH' ni kapsadığını göstermektedir. $\mathrm{Bu}$ işaretlemeler UNEP' in internet sayfasında her bir çalışmanın 
aşağısında kapsadığı SKH şeklinde verilmektedir. Anahtar kavramların önemi ve derinliği göz önüne alındığında bazı konuların daha fazla SKH' ni kapsadığı görülmektedir. En çok SKH' ni kapsayan konular arasında; incelenen çevre 17, çevre yönetimi 14, enerji 9 vb. konular ortaya çıkmaktadır.

Tablo 5. Sürdürülebilir Kalkınma İçin Küresel Hedefler, UNEP Çerçevesinde Karşılaştırma

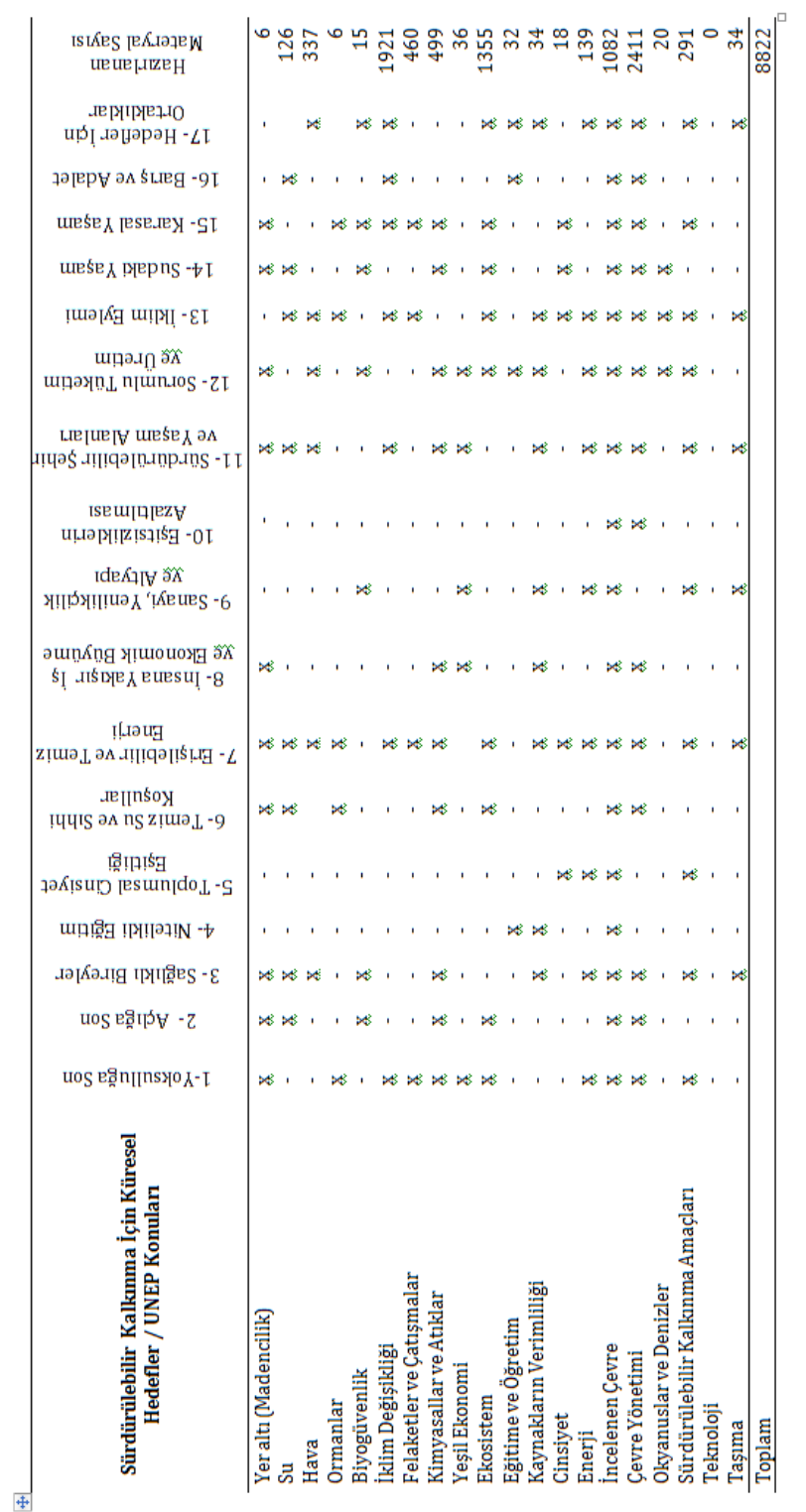

170 | Manisa Celal Bayar Üniversitesi Sosyal Bilimler Dergisi - Cilt: 17, Sayı: 2, Haziran 2019 
4. GAP, DAP, DOKAP, KOP Eylem Planları Çevre-Enerji Bağlamında Ele Alınışı ve UNEP-BM Sürdürülebilir Kalkınma Hedefleri İle Uyumunun Değerlendirmesi

2014-2018 yıllarını kapsayan eylem planları, GAP deneyim ve öncülüğünde, Onuncu Kalkınma Planı ve Bölgesel Gelişme Ulusal Stratejisi (BGUS) dikkate alınarak hazırlanmıştır. Bu anlamda, ortak hedefler bulunmakla birlikte; bölgesel yapının özelliklerine göre değişen unsurlar da yer alabilmektedir. Dolayısıyla planlar oldukça geniş bir kapsama sahip olup, bu çalışmada sadece çevre ve enerji unsurları üzerinde durulmaktadır.

Çalışmamızın bu kısmında, GAP, DAP, DOKAP ve KOP Eylem Planlarında yer alan çevre ve enerji unsurları ile UNEP ve BM-SKH çerçevesindeki hedeflerin uyumunu göstermek üzere Tablo 6.1 ve Tablo 6.2 hazırlanmıştır. Tablodan hareketle elde ettiğimiz çıkarımlar şu şekilde sıralanabilir:

- Yoksulluk, açlık, nitelikli eğitim, cinsiyet eşitliği, eşitsizliklerin azaltılması ve toplumsal barış hedefleri bağlamında SKH ile bölgesel kalkınma planları arasındaki bağıntı daha fazla güçlendirilebilir.

- Temiz su ve sıhhi koşullar, sürdürülebilir şehir ve yaşam alanları, karasal yaşam, sorumlu tüketim ve üretim iklimi en fazla örtüşen hedefler arasında yer almaktadır.

- $\quad$ Çevre yönetimi ile ilgili olarak UNEP, SKH ile ortak 14 hedefe sahipken; bölgesel kalkınma planlarında 7 ortak hedef bulunmaktadır.

- $\quad$ Madencilik konusunda UNEP içerisinde 10 SKH bulunurken; bölgesel kalkınma planlarında bu sayı 3'tür.

- $\quad$ Enerji konusunda UNEP içerisinde 9 SKH bulunurken; bölgesel kalkınma planlarında bu sayı 4-6 arasında değișmektedir.

- IIncelenen çevre konusu başlığında UNEP içerisinde $17 \mathrm{SKH}$ kapsanırken, bölgesel planlar 5 hedefi kapsamaktadır.

- Sağlıklı bireyler hedefinde DOKAP eylem planı, temiz su ve sıhhi koşullar hedefinde GAP eylem planı, erişilebilir ve temiz enerji hedefinde GAP eylem planı, insana yakıșır iş ve ekonomik büyüme hedefinde KOP eylem planı, sanayi, yenilikçilik ve altyapı hedefinde KOP eylem planı, sürdürülebilir şehir ve yaşam alanları hedefinde, GAP ve DAP eylem planları, sorumlu tüketim ve üretim hedefinde DAP ve DOKAP eylem planları, sudaki yaşam hedefinde DOKAP eylem planı, iklim eylemi hedefinde KOP eylem planı ve karasal yaşam hedefinde GAP eylem planı ön sıralarda yer almaktadır.

- $\quad$ Enerji ve çevre konularının birebir ele alındığı alt eksen ve hedefler olarak, GAP Planında Doğal Kaynaklar ve Yenilenebilir Enerji olmak üzere iki başlık yer almaktadır. Bunlardan doğal 
kaynaklara ilişkin hedefler şu şekildedir; "Orman varlığı artırılacak ve barajların erozyondan korunması sağlanacaktır, Bölge'nin doğal kaynak ve hammadde potansiyeli tespit edilecek ve kaynakların ekonomiye kazandırılması kapsamında faaliyetler yürütülecektir, enerji alanında bölge illerindeki üniversitelere özel enerji araştırmaları programı uygulanacaktır". Enerji başlığına ait hedefler kısmında ise; doğalgaz iletim altyapısı güçlendirilecektir, Ilısu Barajı ve HES Projesi tamamlanacaktır, Cizre Barajı ve HES Projesi yaptırılacaktır" ifadesine yer verilmektedir. Bu başlık ve hedefler SKH' nin 5 (Nitelikli Eğitim, Temiz Su ve Sıhhi Koşullar, Erişilebilir ve Temiz Enerji, Insana Yakışır İs ve Ekonomik Büyüme, Sorumlu Tüketim ve Üretim) hedefini kapsamına almaktadır.

- $\quad$ Enerji ve Çevre konularının birebir ele alındığı alt eksen ve hedefler olarak, DAP Planında Çevre ve Enerji olmak üzere iki başlık yer almaktadır. Bunlardan çevreye ilişkin hedefler şu şekildedir; "Taşkın, koruma ve dere ıslahı çalışmaları hızla tamamlanacaktır, toprak koruma ve orman varlığını artırmaya yönelik faaliyetler yaygınlaştırılacaktır, yeraltı ve yerüstü su kaynaklarında su kirliliğinin tespit edilerek su kalitesinin iyileştirilmesine yönelik çalışmalar yapılacaktır, biyolojik çeşitlilik envanter ve izleme projesi gerçekleştirilecektir, "Milli Park" projeleri tamamlanacaktır." Enerji başlığına ait hedefler kısmında ise; "enerji üretimi, iletim ve dağıtım altyapısı güçlendirilecektir, enerji verimliliğini artırmak üzere projeler desteklenecektir, yenilenebilir enerji potansiyeli değerlendirilecektir." ifadesine yer verilmektedir. Bu başlık ve hedefler SKH' nin 5 (Sağlıklı Bireyler, Temiz Su ve Sihhi Koşullar, Erişilebilir ve Temiz Enerji, Sorumlu Tüketim ve Üretim, Sürdürülebilir Şehir ve Yaşam Alanları) hedefini kapsamına almaktadır.

- Enerji ve Çevre konularının birebir ele alındığı alt eksen ve hedefler olarak, DOKAP Planında Çevre ve Sürdürülebilirlik ile Enerji olmak üzere iki başlık yer almaktadır. Bunlardan çevre ve sürdürülebilirlik başlı̆̆ına ilişkin hedefler şu şekildedir; "Milli Park projeleri tamamlanacaktır, biyokaçakçılıkla etkin mücadele sürdürülecektir, ulusal biyolojik çeşitlilik envanter ve izleme projeleri tamamlanacaktır, deniz kirliliği tespit edilecektir, bölgede tarımsal kirliliğin izlenmesi ve azaltılması projesi uygulanacaktır, bölgedeki küçük ve orta ölçekli nehir havzalarında iklim değişikliği ile ortaya çıkabilecek aşırı yağış ve sel (taşkın) koşullarında olası değişiklikler araştırılacaktır." Enerji başlığına ait hedefler kısmında ise; "bölgenin enerji üretim altyapısı iyileștirilecektir, Bölgenin enerji dağıtım altyapısı iyileștirilecektir, Artvin ilinde doğalgaz iletim hatları tamamlanacaktır, Bölgede yenilenebilir enerji çalışmaları

172 | Manisa Celal Bayar Üniversitesi Sosyal Bilimler Dergisi - Cilt: 17, Sayı: 2, Haziran 2019 
desteklenecektir." ifadesine yer verilmektedir. Bu başlık ve hedefler SKH' nin 7 (Sağlıklı Bireyler, Temiz Su ve Sıhhi Koşullar, Erişilebilir ve Temiz Enerji, Sorumlu Tüketim ve Üretim, Sürdürülebilir Şehir ve Yaşam Alanları, Sudaki Yaşam, Ikklim Eylemi) hedefini kapsamına almaktadır.

- $\quad$ Enerji ve Çevre konularının birebir ele alındığı alt eksen ve hedefler olarak, KOP Eylem Planında Çevre Koruma, Enerji Altyapısı ve Yenilenebilir Enerji Altyapısı olmak üzere üç başlık yer almaktadır. Çevre Koruma başlığına ilişkin hedefler şu şekildedir; "Konya kapalı havzasında olası karstik çöküntü alanları belirlenecektir, atık azaltımı ve kaynak verimliliğine yönelik faaliyetler desteklenecektir, Bölgeye ait endemik bitkilerin envanteri çıkarılacak ve ticari kullanım potansiyelleri araştırılacaktır, hava kalitesinin yükseltilmesi ve iklim değişikliğine uyuma yönelik etüt uygulama çalışmaları yapılacaktır." Enerji Altyapısı başlığına ait hedefler kısmında; "enerji altyapısına yönelik çalışmalar yürütülecektir" ifadesine yer verilirken; Yenilenebilir Enerji Altyapısı bölümünde ise; "yenilenebilir enerji kaynaklarına yönelik araştırma, planlama ve destekleme çalışmaları yapılacaktır." denilmektedir. Bu başlık ve hedefler ise SKH' nin 8 (Sağlıklı Bireyler, Temiz Su ve Sihhi Koşullar, Erişilebilir ve Temiz Enerji, Sorumlu Tüketim ve Üretim, Insana Yakışır İş ve Ekonomik Büyüme, Sürdürülebilir Şehir ve Yaşam Alanları, Sudaki Yaşam, Íklim Eylemi) hedefini kapsamına almaktadır.

Temel amaçlar ile SKH arasında birebir bağlantı kurarak uyum derecesini ölçmeye çalışmak hatalı sonuçlar elde edilmesine neden olabilir. Kalkınma projelerinin tüm içeriği doğrultusunda değerlendirme yapmak daha doğru olacaktır. Bütün projelerde de çevre ve enerji konusuna ayrı bir başlık açılarak belli ölçüde vurgu yapılmıştır. 
Tablo 6.1. GAP, DAP, DOKAP, KOP Eyl. Pl.Çevre-Enerji Bağlamında Ele Alınışı ve UNEP-BM Sürdürülebilir Kalkınma Hedefleri ile Uyumunun Değerlendirmesi

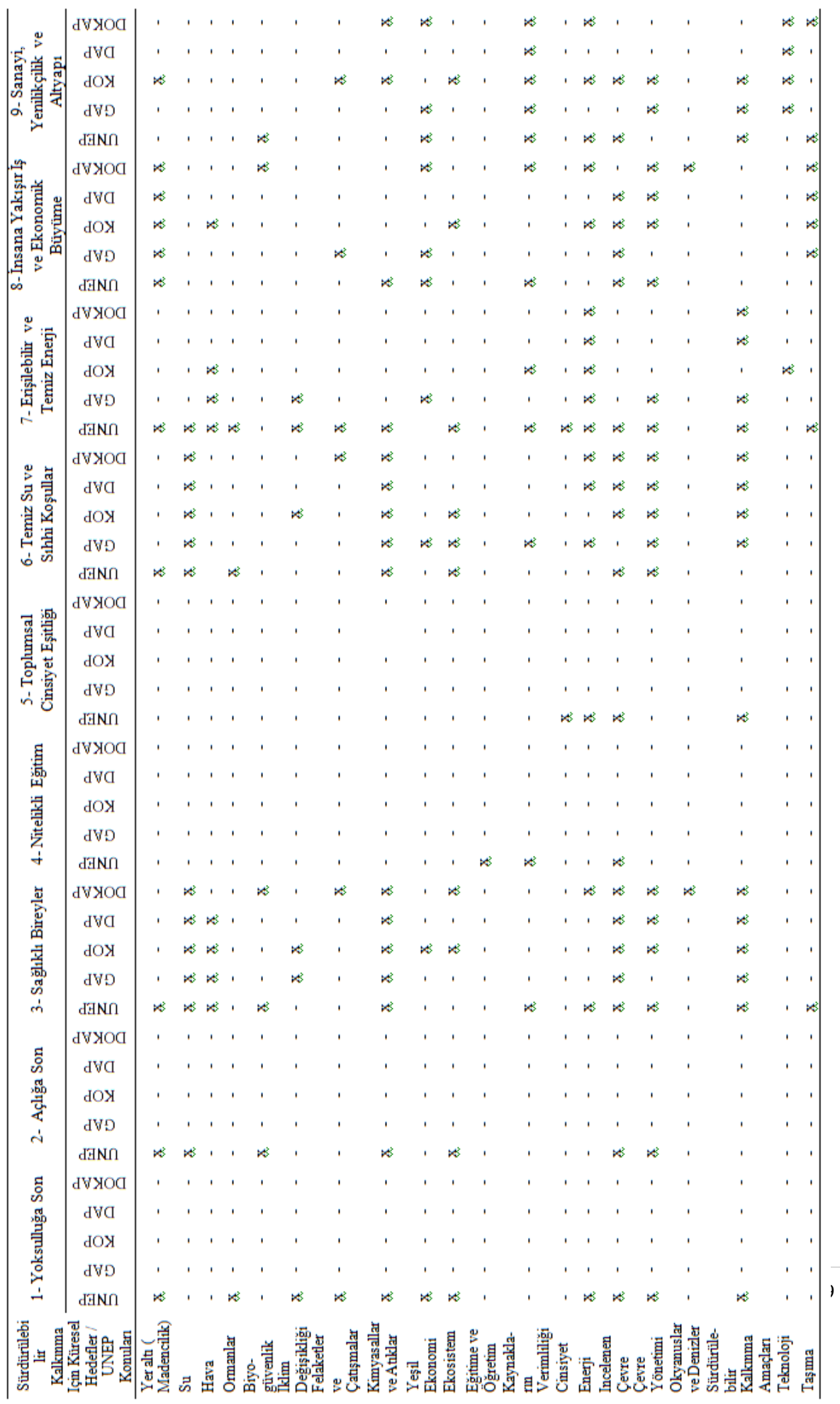


Tablo 6.2. GAP, DAP, DOKAP, KOP Eylem Planları Çevre-Enerji Bağlamında Ele Alınışı ve UNEP-BM Sürdürülebilir Kalkınma Hedefleri ile Uyumunun

Değerlendirmesi

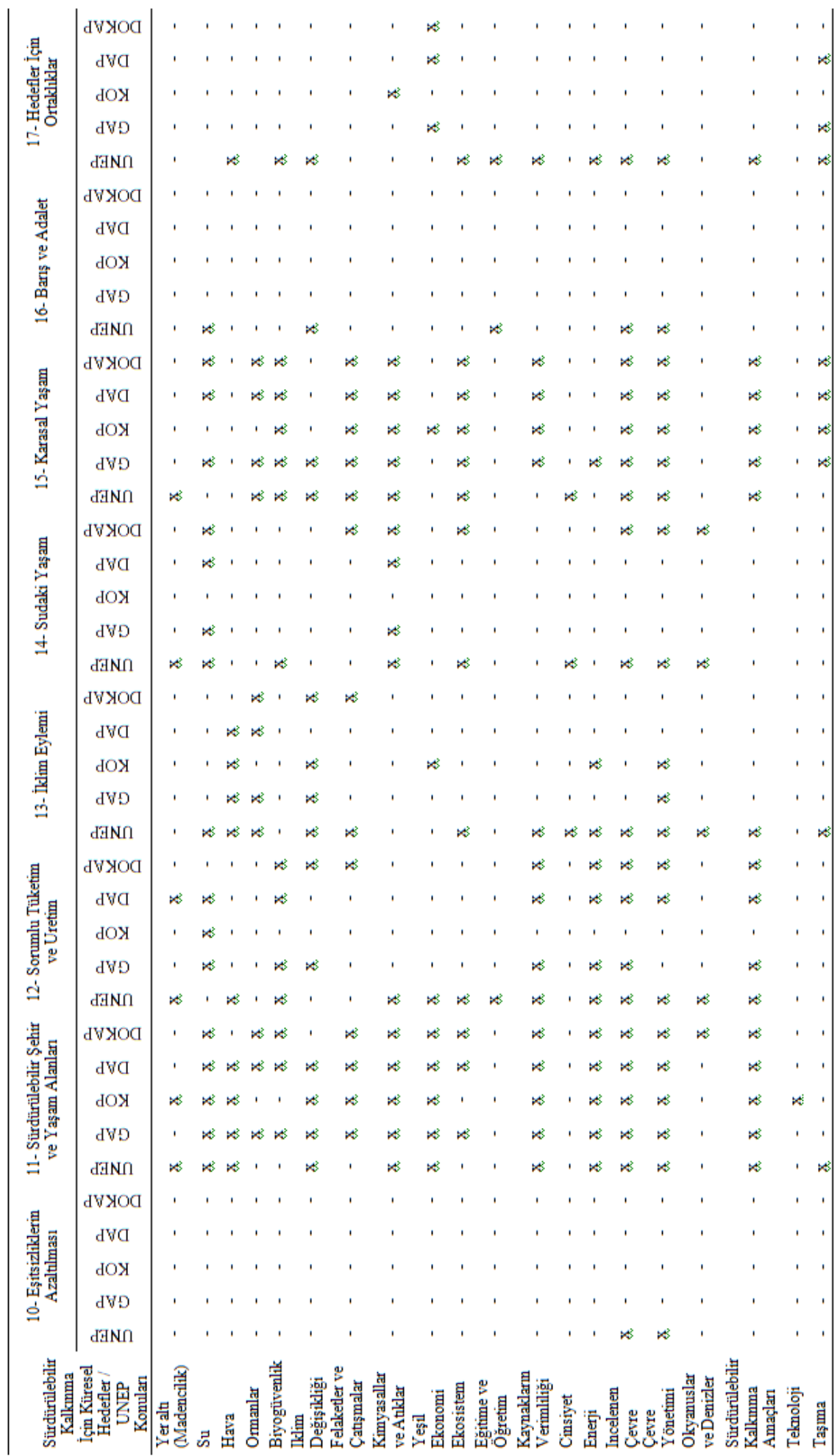




\section{Sonuç ve Öneri}

Planlama anlayışı özellikle bölgesel kalkınmanın sağlanması bakımından önemli sonuçlar ortaya koyabilmektedir. Bilimsel ve teknik alandaki ilerlemeler farklı ihtiyaçlar ve araçları beraberinde getirdiği için, ortaya çıkan yeniliklere göre kalkınma projelerinin güncellenmesinde fayda bulunmaktadır. Bu noktada uluslararası düzeyde belirlenen standartlar, tüm ülkelere yol gösterici bir fonksiyon üstlenmektedir. Hızlı ve güçlü bir büyüme potansiyeline sahip olan Türkiye ekonomisi, başlatılan ve başlatılacak olan yurt içi gelişme projeleri ile kalkınma sürecini daha da güçlendirme yoluna gitmektedir. Ancak bu projelerin şekillendirilmesinde sürdürülebilir kalkınma hedefleri ile uyumun sağlanması, sosyo-ekonomik açıdan, uzun vadede çok daha iyi sonuçların alınmasına katkıda bulunabilecektir.

Bölge planları oluşturulurken bölgenin öncelikleri ile birlikte bölgenin ihtiyaçları da göz önünde bulundurulmalıdır. Ayrıca bölge planları hazırlanırken birbirine benzer planlama anlayışından kaçınılmalı, farklılıklar ortaya çıkarılmalıdır.

Bölge kavramını esas alan bölge kalkınma raporları, bölge içindeki dinamikleri harekete geçirirken aynı zamanda dünya üzerindeki diğer bölgelerin çevre ve sürdürülebilir hassasiyetlerini de hatırlamalıdır. Sac ayakları sağlam olan bir bölgesel kalkınma raporu bugünü ve geleceği kapsama noktasında daha başarılı olabilecektir.

\section{Kaynakça}

Akpınar, R., Taşçı, K., ve Özsan. M. E., (2011), Teoride ve Uygulamada Bölgesel Kalkınma Politikaları, Ekin Kitabevi, Bursa.

Arslan, K., (2005). Bölgesel Kalkınma Farklılıklarının Giderilmesinde

Etkin Bir Araç: Bölgesel Planlama ve Bölgesel Kalkınma Ajansları, İstanbul Ticaret Üniversitesi Sosyal Bilimler Dergisi, 4(7), 275294.

Berber, M., Çelepçi, E., (2005), Türk Bölgesel Kalkınma Politikalarında Yeni Arayışlar: Kalkınma Ajansları ve Türkiye' de Uygulanabilirliği, Doğu Karadeniz Bölgesel Kalkınma Sempozyumu, 13-14.

D.P.T., (1977), Dördüncü Beş Yıllık Kalkınma Planı (1978- 1982). Şehirleșme, Bölgesel Gelişme, Kentleșme, Konut, Özel İhtisas Komisyonu Raporu, Yayın No: 1536, ÖİK: 230, Ankara. 
Türkiye' de Bölgesel Çalışmalar: GAP, DAP, DOKAP ve KOP Planlarının Çevre ve Enerji Bağlamında Değerlendirilmesi, Sürdürülebilir Kalkınma Hedefleri ile Uyumunun Karşılaştırılması

D.P.T., (2000), Sekizinci Beş Yıllık Kalkınma Planı (2001- 2005). Bölgesel Gelişme, Özel İhtisas Komisyonu Raporu, Yayın No: 2502, ÖİK: 523, Ankara.

D.P.T., (2006), Dokuzuncu Beș Yıllık Kalkınma Planı (2007- 2013), Ankara.

Dinler, Z., (2014), Bölgesel İktisat, 10. Baskı, Ekin Kitabevi, Bursa.

Efe, M., Akgül, B., (2011), Türkiye'de Bölgelemenin Temel Veri Alanları ve Bölgesel Kalkınma Model Çalışmaları, Ekin Kitabevi, Bursa.

Eraydın, A., (2004), Bölgesel Kalkınma Kavram, Kuram ve Politikalarında Yaşanan Değisşimler, Kentsel Ekonomik Araştırmalar Sempozyumu, Cilt 1, s.136.

Göymen, K., (2005), Türkiye' de Bölge Politikalarının Evrimi ve Bölgesel Kalkınma Ajansları, 35-60.

Gündüz, A. Y., (2006), Bölgesel Kalkınma Politikası, Ekin Kitabevi, Bursa.

Halisçelik, E., (2015), Binyıl Kalkınma Hedefleri ve Yoksul Odaklı Büyüme, Gazi Kitabevi, Ankara.

Kalkınma Bakanlığı, (2014), GAP Eylem Planı 2014-2018, Ankara. Kalkınma Bakanlığı, (2014), KOP Eylem Planı 2014-2018, Ankara.

Kalkınma Bakanlığı, (2014), DAP Eylem Planı 2014-2018, Ankara.

Kalkınma Bakanlığı, (2014), DOKAP Eylem Planı 2014-2018, Ankara.

Kara, M. A., (2013), Bölgesel Ekonomi Teori ve Politikalar, Orion Kitabevi, Ankara.

Karakılçı,Y., (2014), Yeni Bölgeselleşme Politikaları ve Türkiye'de Bölge Yönetimi, Seçkin Kitabevi, Ankara.

Sevinç, H., (2011), Bölgesel Kalkınma Sorunsalı: Türkiye' de Uygulanan Bölgesel Kalkınma Politikaları, Girişimcilik ve Kalkınma Dergisi, 6(2), 35-54.

Tiftikçigil, B.Y., (2010), Türkiye'de Bölgesel Kalkınma Politikalarında Yaşanan Dönüşüm ve Kalkınma Ajansları, Derin Yayınları, İstanbul.

http://www.kop.gov.tr/sayfalar/tarihi-surec/61,Tarihi Süreç, (Son Erişim Tarihi: 14.11.2017)

http://unesco.org.tr/dokumanlar/duyurular/skh.pdf, 2030

Sürdürülebilir Kalkınma Hedefleri, (Son Erişim Tarihi: 30.11.2017)

https://www.unenvironment.org/about-un-environment, Who We Are, (Son Erişim Tarihi: 30.11.2017) 
178 | Manisa Celal Bayar Üniversitesi Sosyal Bilimler Dergisi - Cilt: 17, Sayı: 2, Haziran 2019 